\section{Autoantikörper gegen Einzelstrang-DNA}

W. Stöcker und W. Schlumberger

Euroimmun Medizinische Labordiagnostika AG, Lübeck, Deutschland

Synonym(e) Autoantikörper gegen ssDNA; Autoantikörper gegen ssDNA; Anti-ssDNA-Antikörper

Englischer Begriff autoantibodies to ssDNA

Definition Autoantikörper gegen DNA lassen sich in 2 Gruppen unterscheiden: Antikörper gegen doppelsträngige, native DNA (Doppelstrang-DNA, dsDNA, nDNA; $>$ Autoantikörper gegen Doppelstrang-DNA) und Antikörper gegen einzelsträngige, denaturierte DNA (Einzelstrang-DNA, ssDNA). Antikörper gegen dsDNA reagieren mit Epitopen, die im Desoxyribosephosphatgerüst der DNA (außen) liegen, wohingegen sich Antikörper gegen ssDNA vorwiegend an Epitope aus dem Bereich der Purin- und Pyrimidinbasen binden.

Untersuchungsmaterial Serum, Plasma.

Probenstabilität Autoantikörper sind bei $+4{ }^{\circ} \mathrm{C}$ bis $\mathrm{zu}$ 2 Wochen lang beständig, bei $-20^{\circ} \mathrm{C}$ über Monate und Jahre hinweg.

Analytik Autoantikörper gegen ssDNA gehören vorwiegend der Immunglobulinklasse $\operatorname{IgG}$ an und werden mittels - Enzymimmunoassay bestimmt, mit hitzedenaturierter DNA an der Festphase. Die Speziesquelle zur Aufreinigung der DNA spielt keine Rolle, da DNA eine hochkonservierte
Struktur darstellt und frei von assoziierten Proteinen sein sollte.

Durch indirekte Immunfluoreszenz ( $\triangleright$ Immunfluoreszenz, indirekte) werden Antikörper gegen ssDNA weder mit HEp-2-Zellen noch mit Crithidia luciliae erfasst, weil hier die DNA in nativer Form vorliegt und die entsprechenden Epitope zum größten Teil verdeckt sind.

Referenzbereich - Erwachsene Negativ.

Referenzbereich - Kinder Negativ.

Indikation Keine, da Antikörper gegen ssDNA bei verschiedenen Erkrankungen vorkommen können und keinen differenzialdiagnostischen Nutzen haben.

Diagnostische Wertigkeit Die Bestimmung der Autoantikörper gegen ssDNA spielt diagnostisch keine entscheidende Rolle. Während Autoantikörper gegen dsDNA nahezu ausschließlich bei Patienten mit systemischem Lupus erythematodes (SLE) zu finden sind, kommen Autoantikörper gegen ssDNA mit hoher Prävalenz zusätzlich auch bei vielen anderen Erkrankungen des rheumatischen Formenkreises vor (s. Tabelle).

Prävalenz von Autoantikörpern gegen Einzelstrang-DNA bei ausgewählten Erkrankungen:

\begin{tabular}{|l|l|}
\hline Erkrankung & Prävalenz (\%) \\
\hline Progressive Systemsklerose & 44 \\
\hline Sjögren-Syndrom & 40 \\
\hline Polymyositis/Dermatomyositis & 43 \\
\hline Rheumatoide Arthritis & 12 \\
\hline Gesunde Blutspender & $5-10$ \\
\hline
\end{tabular}

